\author{
Kamila MarszaŁek, Kinga Herda, PaweŁ P. ŁaBaJ, Wojciech Branicki \\ Małopolskie Centrum Biotechnologii Uniwersytet Jagielloński \\ ul. Gronostajowa 7A; 30-387 Kraków \\ E-mail: wojciech.branicki@uj.edu.pl
}

\title{
GENY ARCHAICZNYCH LUDZI W GENOMIE CZŁOWIEKA WSPÓŁCZESNEGO A PANDEMIA COVID-19
}

\section{SEKWENCJE GENOMÓW \\ ARCHAICZNYCH LUDZI POTWIERDZAJA \\ UDZIAE INTROGRESJI W EWOLUCJI CZŁOWIEKA WSPÓŁCZESNEGO}

Przeniesienie materiału genetycznego $z$ jednego gatunku do puli genów innego gatunku to zjawisko znane jako introgresja. Pośrednich dowodów na przepływ genów archaicznego człowieka do puli genów człowieka współczesnego dostarczyły badania populacyjne, a także analiza sekwencji genomów człowieka i szympansa (ZIETKIEWICZ i współaut. 2003, Wills 2011). Postęp w technologii sekwencjonowania DNA, który nastapił $\mathrm{w}$ ostatnich kilkunastu latach, umożliwił uzyskanie bezpośrednich dowodów na obecność introgresji w genomie człowieka współczesnego. Zastosowanie zaawansowanych narzędzi bioinformatycznych i statystycznych do danych uzyskanych $z$ sekwencjonowania genomów człowieka współczesnego i spokrewnionych gatunków Neandertalczyków i Denisowian umożliwiło określenie stopnia przepływu genów, a także pozwoliło na postawienie hipotez o ich znaczeniu funkcjonalnym. Pierwszych przełomowych danych o obecności genów neandertalskich w naszym DNA dostarczyła analiza sekwencji genomu Neandertalczyka $z$ jaskini Vindija $w$ Chorwacji (GREEN i współaut. 2010). Zostały one później potwierdzone przez lepsze jakościowo sekwencje neandertalskiego DNA, a dodatkowo, również poprzez sekwencje DNA genomu jeszcze jednego wymarłego kuzyna człowieka współczesnego, którego szczątki odkryto $\mathrm{w}$ jaskini Denisowa na Syberii (KRAUSE i współaut. 2010). Do koegzystencji Neandertalczyków i ludzi współczesnych na terenach Europy przed kilkudziesięcioma tysiacami lat przywykliśmy dzięki licznym doniesieniom $z$ badań wykopaliskowych. Jednak uzyskanie sekwencji DNA kolejnego krewnego człowieka współczesnego, $\mathrm{z}$ paliczka odkrytego $\mathrm{W}$ jaskini Denisowa, było już spora sensacją w świecie naukowym. Sekwencjonowanie DNA potwierdziło występowanie znaczących różnic genetycznych pomiędzy Neandertalczykami a Denisowianami sugerując, że gatunki te miały wspólnego przodka około 380 tys. lat temu (RACIMO i współaut. 2015, RogERS i współaut. 2020). Sekwencjonowanie genomów ludzi prehistorycznych i współczesnych, a także porównanie otrzymanych sekwencji pozwoliło na lepsze poznanie naszej historii ewolucyjnej.

Do krzyżowania ludzi współczesnych $z$ Neandertalczykami doszło co najmniej dwukrotnie, a drugie zdarzenie hybrydyzacji, które nastapiło ok. 50 tys. lat temu, pozostawiło ślad $\mathrm{w}$ postaci ponad $1 \%$ obecności genów neandertalskich $\mathrm{w}$ genomach wszystkich współczesnych ludzi żyjących poza Afryka. Z przeprowadzonych analiz wynika, że nieco więcej DNA neandertalskiego można znaleźć w Azji Wschodniej (ok. 2,3-2,6\%) niż w populacjach Zachodniej Europy (ok. 1,8$2,4 \%)$. Trudno uwierzyć, ale łącznie w puli genów Europejczyków znajduje się aż 2030\% DNA neandertalskiego (VERNOT i AKEY 2014). Co więcej, w niektórych, specyficznych rejonach poziom introgresji neandertalskiej może sięgać nawet $64 \%$ w przypadku

Słowa kluczowe: adaptacja, badania paleogenetyczne, ewolucja człowieka, geny wymarłych gatunków ludzkich a COVID-19, introgresja denisowiańska, introgresja neandertalska 
Europejczyków i 62\% w przypadku Azjatów (SANKARARAMAN i współaut. 2014, RACIMO i współaut. 2015, DOLGOVA i LAO 2018, RINKER i współaut. 2020). Najnowsze badania sugeruja, że DNA Neandertalczyków w niewielkim stopniu (ok. 0,3\%) jest również obecny w Afryce Subsaharyjskiej, co tłumaczone jest powrotem części populacji europejskiej, posiadającej już domieszkę genów neandertalskich, do Afryki, do którego doszło ok. 20 tys. lat temu (CHEN i współaut. 2020). Do krzyżowania ludzi współczesnych z Denisowianami musiało dojść przed kolonizacja Australii i Nowej Gwinei. U rdzennych mieszkańców rejonu Pacyfiku poziom genów denisowiańskich wynosi nawet do 6\%. Nieznaczny odsetek genów denisowiańskich (ok. 0,2\%) znajduje się również w populacjach zamieszkujacych tereny Południowej i Wschodniej Azji. Niewykluczone, że dalsze badania zweryfikuja jeszcze część informacji na temat introgresji $w$ genomie człowieka, ale przepływ genów pomiędzy człowiekiem współczesnym a jego bliskimi krewnymi, który nastapił po wyjściu człowieka współczesnego $z$ Afryki, nie podlega już dziś dyskusji i ma duże znaczenie nie tylko dla poznania historii ewolucyjnej człowieka, lecz również lepszego zrozumienia działania genów człowieka współczesnego.

Przyjmuje się, że większa liczba alleli neandertalskich musiała mieć szkodliwy wpływ na ogólne dostosowanie naszych przodków. Szkodliwość mogła wynikać w dużym stopniu $z$ większego obciążenia genomów Neandertalczyków i Denisowian mało szkodliwymi allelami, które gromadziły się $z$ powodu słabej efektywności doboru oczyszczajacego w małych populacjach Neandertalczyków i Denisowian. Oszacowano, że domieszka genów neandertalskich w genomie człowieka współczesnego mogła wynosić pierwotnie aż $\sim 10 \%$, jednak na skutek działania doboru oczyszczającego spadła do obserwowanych obecnie ok. 2\% u współczesnych Azjatów i Europejczyków (HARRIS i NIELSEN 2016). Długotrwałe działanie doboru oczyszczajacego doprowadziło do powstania w naszym genomie tzw. archaicznych pustyń, czyli regionów szczególnie ubogich w warianty pochodzace od człowieka archaicznego (VERNOT i współaut. 2016). Brak alleli archaicznych ludzi jest szczególnie widoczny w przypadku genów ulegajacych ekspresji w męskich gonadach, a także określonych regionach mózgu, szczególnie w rozwijającej się korze mózgowej i dojrzałym prążkowiu. Występowanie rozległej archaicznej pustyni stwierdzono np. na odcinku o długości $11 \mathrm{Mb}$ na chromosomie 7, w którym znajduje się gen FOXP2 związany $z$ mowa i językiem, a także geny zwiazane $z$ zaburzeniami ze spektrum auty- zmu (VERNOT i współaut. 2016, DANNEMANN i Racimo 2018). Silne działanie doboru widoczne jest również w obrębie chromosomu $\mathrm{X}$. Wydaje się, że mogło ono być spowodowane sterylnościa lub zmniejszeniem płodności u mężczyzn, do której dochodziło u mieszańców.

Szczególnie interesujace jest to, że introgresja niektórych genów neandertalskich, które znajdujemy we współczesnych genomach, mogła zapewnić przybyłemu na teren Europy człowiekowi współczesnemu istotne korzyści adaptacyjne. Świadczy o tym wysoka częstość wariantów neandertalskich niektórych genów we współczesnej populacji europejskiej (HUERTA-SÁNCHEZ i CASEY 2018). W krótkim okresie, dzięki hybrydyzacji, człowiek współczesny uzyskał korzyści adaptacyjne, które u Neandertalczyków pojawiły się na skutek trwajacej wiele tysięcy lat ewolucji umożliwiajacej lepsze przystosowanie do warunków panujących na terenie Europy (ABI-RACHED i współaut. 2011, MENDEZ i współaut. 2013, SANKARARAMAN i współaut. 2014, VERNOT i AKEY 2014, DANNEMANN i współaut. 2016). Podobne znaczenie ewolucyjne mogła również przynieść introgresja denisowiańska, która obecna jest w genomach w regionie Pacyfiku i Azji (HuERTA-SÁNCHEZ i współaut. 2014). Warto podkreślić, że introgresja adaptatywna nie jest uważana za zjawisko częste. Wydaje się, że częściej zachodzi w genach polimorficznych, ale w takiej sytuacji rzadko prowadzi do utrwalenia, a raczej utrzymuje się jako kolejny wariant. Co ciekawe, $z$ przeprowadzonych analiz wynika, że geny które zawdzięczamy zjawisku introgresji, dały naszemu gatunkowi różne korzyści adaptacyjne. Migracje człowieka wiązały się $z$ koniecznościa przystosowania się do różnych środowisk $i$ do istotnych zmiennych srodowiskowych, do których $z$ pewnościa zaliczyć należy ilość promieniowania ultrafioletowego. Pigmentacja skóry pełni istotna funkcję modulatora ilości UV, docierajaccego do jej głębszych warstw. Eumelanina chroni przed jego destruktywnym nadmiarem, ale $\mathrm{w}$ regionach o niższej intensywności UV nadmiar tego ciemnego pigmentu jest niepożądany, gdyż może blokować syntezę witaminy D (JABLONSKI 2021). Co ciekawe, ślady introgresji neandertalskiej wykryto w regionie p21.31 chromosomu 3, w którym zlokalizowany jest gen HYAL2 zaangażowany $\mathrm{w}$ odpowiedź komórkowa na promieniowanie ultrafioletowe. $Z$ przeprowadzonych badań wynika, że wariant nabyty od Neandertalczyka pozostawał pod wpływem silnego pozytywnego doboru w populacji zamieszkujacej rejon Wschodniej Azji (DING i współaut. 2014). Nie jest do końca jasne, czy introgresja denisowiańska mogła 
kształtować pigmentacje człowieka współczesnego, ale uważa się, że mogła mieć znaczenie w zwiększeniu ilości pigmentu skóry, korzystnym w regionie Wybrzeża Azji Południowej i Południowo-Wschodniej, Melanezji i Australii (JABLONSKI 2021). Jak sugeruja badacze, geny okalajace gen $B N C 2$, odpowiadajace za pigmentację skóry i występowanie piegów, maja pochodzenie neandertalskie (DANNEMANN i Kelso 2017).

Głośnym przypadkiem adaptacji poprzez introgresje jest przystosowanie populacji Tybetu do życia na dużych wysokościach, w warunkach niskich temperatur i niskiego ciśnienia tlenu. Dwa geny: EGLN1 i EPAS1, odgrywają istotna rolę $\mathrm{w}$ adaptacji do tych trudnych warunków środowiskowych. Co ciekawe, rzadkie gdzie indziej warianty tych genów, a obserwowane $z$ wysoką częstościa u mieszkańców Tybetu, sa odpowiedzialne za wytworzenie tego specyficznego uwarunkowania fizjologicznego. Tybetańczycy różnia sie pod tym wzgledem od innych populacji zamieszkujących wysoko położone tereny, np. południowo-amerykańskiej populacji żyjacej w Andach. Dzięki obecności określonych wariantów genów EPAS1 i EGLN1 mieszkańcy Tybetu nie sa narażeni na występowanie nadciśnienia płucnego zwiąanego ze zwężeniem naczyń krwionośnych, ani na wzrost stężenia hemoglobiny we krwi (zwiąany $z$ podwyższonym ryzykiem wystapienia przewlekłej choroby wysokościowej). Analiza sekwencji DNA wymienionych wyżej genów potwierdziła, że korzystne allele sa wynikiem introgresji genów Denisowian (HUERTA-SÁNCHEZ i współaut. 2014, HUERTA-SÁNCHEZ i CASEY 2015, HACKINGER i współaut. 2016, ZHANG i współaut. 2020).

Warto zauważyć, że zmiana istotnego czynnika decydującego o przystosowaniu organizmu do danego środowiska może sprawić, że faworyzowane dotąd allele moga stać się szkodliwe, stając się np. czynnikiem ryzyka rozwoju chorób (SIMONTI i współaut. 2016, QUACH i QUINTANA-MURCI 2017). Badania dotyczace znaczenia czynników genetycznych w zwiększonym ryzyku występowania cukrzycy typu 2 u ludności zamieszkującej Meksyk i Amerykę Łacińską wykazały, że znajdujący się $\mathrm{w}$ regionie $17 \mathrm{p} 13.1$ gen SLC16A11 jest zwiąany $z$ występowaniem tej choroby. Haplotyp (segment DNA odziedziczony od jednego $z$ rodziców, w którym może znajdować się wiele genów) zwiększajacy ryzyko zachorowania na cukrzyce typu 2 zawiera cztery mutacje nukleotydowe typu zmiana sensu (zmieniające sekwencję białka) oraz jedną mutację cicha w genie SLC16A11 $i$ jest on obecny u około $50 \%$ mieszkańców Meksyku i Ameryki Łacińskiej, 10\% mieszkańców Wschodniej Azji, bardzo rzadko wy- stępuje jednak u Europejczyków i Afrykanów. Białko SLC16A11 w wątrobie wpływa na metabolizm tłuszczy, prawdopodobnie powodujac podniesienie poziomu wewnattrzkomórkowego triacyloglicerolu. Co ciekawe, w warunkach niedoboru pożywienia haplotyp ten jest korzystny i wpływa na wzrost przeżywalności, dlatego $\mathrm{w}$ przeszłości mógł być faworyzowany przez dobór naturalny. Współcześnie efekt jest przeciwny, haplotyp zwiększa ryzyko otyłości i prowadzi do insulinooporności. Z przeprowadzonych analiz wynika, że istotne warianty genu SLC16A11 mogły znaleźć się w genomie współczesnego człowieka za sprawa introgresji neandertalskiej, która w zamierzchłych czasach pomogła przetrwać warunki głodu, a dziś jest obciażeniem prowadzacym do cukrzycy (THE Sigma Type 2 Diabetes Consortium 2014).

Przykładów obecności archaicznych wariantów w genomie człowieka współczesnego, które mogły pomóc w adaptacji do specyficznych warunków środowiskowych jest więcej (Tabela 1) (DANnEMAnN i Racimo 2018, DolGOVA i LAO 2018). W artykule tym zwracamy uwage szczególnie na te, które pozwoliły na zwiększenie prawdopodobieństwa przeżycia $\mathrm{w}$ przypadku kontaktu człowieka $z$ patogenami. Warto wobec tego lepiej przyjrzeć się genom decydujacym o lepszym dostosowaniu organizmu do walki $z$ patogenami.

\section{INTROGRESJA GENÓW ZWIAZANYCH $Z$ UKEADEM ODPORNOSCIOWYM CZŁOWIEKA I ISTOTNYCH W WALCE $Z$ PATOGENAMI}

Geny Neandertalczyków i Denisowian, które sa obecne w genomach współczesnego człowieka, maja wpływ na wiele różnych procesów molekularnych zachodzacych w naszych organizmach, w tym na odpowiedź immunologiczna skierowana przeciw różnego typu patogenom (ALMARRI i współaut. 2020). $Z$ przeprowadzonych analiz wynika, że wirusy mogły być jednym $z$ bardziej istotnych czynników promujacych introgresję adaptacyjna. Musiało się to wiązać $z$ ekspozycja obu gatunków na nowe wirusy, a jednocześnie $z$ przepływem genów istotnych $\mathrm{w}$ walce $\mathrm{z}$ zakażeniem tymi wirusami. Rzeczywiście, okazuje się, że w genomie współczesnych ludzi obecnych jest bardzo wiele długich segmentów DNA pochodzenia neandertalskiego, które sa wyjątkowo bogate w sekwencje kodujace białka zaangażowane $\mathrm{w}$ interakcje $\mathrm{z}$ wirusami. Białka te moga pełnić różne funkcje w zakresie szeroko rozumianej obrony przeciwwirusowej. Niekoniecznie musza to być białka układu odpornościowego, ale wpływając na ograniczenie replikacji wirusa, czy też ła- 
godzac szkodliwe skutki infekcji wirusowej, zapewniaja lepsze dostosowanie do walki $z$ infekcjami. Niektóre archaiczne geny kodujące tego typu białka mogły podlegać pozytywnej selekcji dzięki ochronie, jaka zapewniały człowiekowi współczesnemu w walce $z$ nowymi wirusami. Co ciekawe, $z$ przeprowadzonych analiz wynika, że te archaiczne warianty $w$ naszych genomach koduja białka pomagające głównie w walce $z$ wirusami RNA (ENARD i współaut. 2018). Taki wynik dodatkowo wzmacnia hipotezę o introgresji adaptacyjnej $\mathrm{w}$ odpowiedzi na kontakt $z$ nowymi patogenami, gdyż to właśnie wirusy RNA mają większa zdolność do przenoszenia się międzygatunkowego niż wirusy DNA, a więc stanowiły większe zagrożenie w czasie hybrydyzacji człowieka współczesnego $z$ archaicznym (KREUDER JOHNSON i współaut. 2015, GEOGHEGAN i współaut. 2017).

Introgresję neandertalska $\mathrm{w}$ genomie człowieka zaobserwowano $\mathrm{w}$ przypadku wariantów DNA zaangażowanych w odpowiedź na zakażenie wirusem grypy typu A (IAV) (QUACH i współaut. 2016), a także wirusami $z$ rodziny flawiwirusów, do których należa np. wirus zapalenia watroby typu C (HCV) czy wirus dengi (SAms i współaut. 2016). Neandertalska introgresja doprowadziła do podniesienia ekspresji genu PPIE, który hamuje tworzenie wirusowego kompleksu rybonukleoproteinowego wymaganego do replikacji RNA wirusa IAV (ENARD i PETROV 2018). Możliwe, że taka zwiększona ekspresja powoduje większe hamowanie wirusowego kompleksu rybonukleoproteinowego, a tym samym zwiększona odporność na wirusa. W odpowiedzi na zakażenie flawiwirusami $\mathrm{w}$ walce $\mathrm{z}$ infekcja moga być pomocne archaiczne sekwencje genu OAS1, który po indukcji przez interferony koduje białko aktywujace RNaze L i prowadzi do degradacji wirusowego RNA i zahamowania replikacji wirusa. Dowiedziono, że OAS1 występujacy u człowieka współczesnego przejawia mniejszą aktywność enzymatyczną niż wariant pochodzacy od Neandertalczyków. Możliwe, że nabyty od Neandertalczyków wariant genu OAS1 kodujący białko o większej aktywności enzymatycznej, stał się korzystny dla przetrwania człowieka współczesnego na terenie Europy. Zbyt kosztowny do utrzymania w Afryce, w konfrontacji $z$ nowym zagrożeniem ze strony wirusów RNA w Europie był faworyzowany przez dobór naturalny (ZEBERG i PÄÄBO 2021). Obecność introgresji pochodzenia neandertalskiego wykazano również $\mathrm{w}$ przypadku kompleksu genów HLA kodujących antygeny zgodności tkankowej odpowiedzialne za regulacje układu odpornościowego. Archaiczne warian- ty HLA mogły być istotne dla przetrwania człowieka współczesnego w nowym środowisku, zwiększając jego szanse na przeżycie. Teza ta jest mocno wspierana przez wyniki badań wskazujacce, że allele HLA klasy I pochodzenia archaicznego stanowia 50$85 \%$ wariantów HLA w populacjach Eurazji, mimo że ilość ogólnych dziedziczonych genów archaicznych wynosi około 1-6\% (QUACH i współaut. 2016). Wykazano, że jeden $z$ takich wariantów silniej reaguje na europejski podtyp wirusa HIV-B. Co ciekawe, populacyjne różnice w zakresie wariantów HLA moga być odpowiedzialne za różnicowanie i ewolucję patogenów takich jak wirus Zika, wirus zapalenia wattroby typu B (HBV), wirus odry, HCV, a także SARS-CoV-2 (KIST i współaut. 2020). Hybrydyzacja ludzi współczesnych i archaicznych musiała wiązać się $z$ międzygatunkowa transmisją wirusów, również tych przenoszonych droga płciowa. Jedna $\mathrm{z}$ prac sugeruje, $\dot{z} \mathrm{e}$ adaptacja do konkretnych nisz i interakcje między gospodarzem a wirusem wpłynęły znacząco na ewolucję zarówno człowieka, jak i wirusa. Badania wykazały, że pewne warianty HLA, popularne w szczególności wśród mieszkańców Eurazji i Malezji, włączone do genomu człowieka współczesnego w wyniku introgresji adaptacyjnej, poza potencjalnym pozytywnym wpływem na sukces reprodukcyjny, związane sa również $z$ podwyższonym ryzykiem zachorowania na raka szyjki macicy w wyniku zakażenia wirusem HPV. Sugeruje to, że introgresja i następujące działanie doboru na układ immunologiczny może prowadzić do licznych kompromisów ewolucyjnych (CHEN i współaut. 2018). Warianty, które pomagaja w walce $z$ jednym patogenem, moga zwiększać podatność na inny lub też zwiększać ryzyko autoimmunizacji lub innych chorób niewywoływanych przez patogeny. Inne przykłady lokalnych adaptacji i wywieranych przez nie efektów znajduja się w Tabeli 1.

\section{ZNACZENIE GENÓW NEANDERTALSKICH W STARCIU $Z$ WIRUSEM SARS-COV-2}

COVID-19 jest nowa choroba powodowaną przez wirusa SARS-CoV-2, którą po raz pierwszy oficjalnie zaobserwowano w prowincji Hubei w Chinach w grudniu 2019 r. Wirus SARS-CoV-2, powodujący ciężki ostry zespół oddechowy SARS (od ang. severe acute respiratory syndrome), zostal wyizolowany $\mathrm{z}$ zainfekowanych komórek ludzkich 12 stycznia 2020 r. i sklasyfikowany jako siódmy koronawirus mogacy zakażać komórki ludzkie. Analiza filogenetyczna pełnego genomu wykazała, że SARS-CoV-2 wykazuje 
podobieństwo w stopniu $91,02 \%$ do wcześniej zidentyfikowanego SARS-CoV-1 (GHAFOURI-FARD i współaut. 2020). Koronawirusy należą do rodziny Coronaviridae, rzędu Nidovirales, wirusów zawierających jednoniciowy RNA. Genom koronawirusów ma długość około 26-30 tysieccy zasad i zawiera geny kodujace białka potrzebne do replikacji wirusa, modulacji odpowiedzi immunologicznej i formowania jego struktury (PANCER i współaut. 2020). Biorac pod uwage powszechność występowania, wysoką zmienność genetyczna i szybka rekombinację genomów koronawirusów, a także rosnace interakcje pomiędzy ludźmi a zwierzętami, częstość infekcji międzygatunkowych prawdopodobnie będzie wzrastać (WANG H. i współaut. 2020, ZHANG i współaut. 2020).

Pochodzenie wirusa SARS-CoV-2 wciąż podlega dyskusji. Analizy genetyczne sugeruja, że sekwencja RNA wirusa SARS-CoV-2 wykazuje 96\% podobieństwa do genomu koronawirusa nietoperzy zamieszkujących prowincje Yunnan - BatCoV RaTG13. Jednak na przykładzie wykrytych wcześniej wirusów SARS-CoV-1 i MERS-CoV udowodniono, że do zakażenia człowieka potrzebny jest jeszcze pośredni gospodarz, np. wielbłąd lub cyweta. W październiku 2019 r., a więc w kilka miesięcy przed wybuchem pandemii, chińscy naukowcy odkryli w próbkach pobranych od martwych łuskowców formy podobne do SARS-CoV-2, co może sugero- wać, że organizmy te pełnią rolę gospodarzy pośrednich. Porównanie genomu wirusa pobranego od łuskowców (Pangolin-CoV) Z genomem wirusa SARS-CoV-2 pobranego $z$ komórek ludzkich i wirusa BatCoV wykazało średnio 95,41\% podobieństwa do SARS-CoV-2 i średnio 97,48\% podobieństwa do BatCoV sugerujacc, że łuskowiec mógł być nosicielem nowego koronawirusa (WANG $\mathrm{H}$. i współaut. 2020, ZHANG i współaut. 2020).

Pandemia COVID-19 zaktywizowała naukowców reprezentujących większość dyscyplin naukowych, co przyczyniło się do dobrego poznania samego wirusa, sposobów jego rozprzestrzeniania się, a także reakcji organizmu człowieka $w$ starciu $z$ patogenem. Prowadzone statystyki wykazały, że nie tylko sam wiek człowieka, który jest najistotniejszym czynnikiem, ale również stan organizmu osoby zakażonej i jej płeć daja informację o prawdopodobnym przebiegu choroby. Do chorób zwiększajacych ryzyko ciężkiego przebiegu zakażenia SARS-CoV-2 zaliczono m.in.: nowotwory, przewlekłe choroby nerek, przewlekłe choroby płuc, demencje, chorobę Alzheimera, cukrzyce, choroby układu krażenia, AIDS czy nadwagę. W grupie podwyższonego ryzyka znalazły się również np.: kobiety w ciąży, osoby palące i nadużywające alkoholu czy narkotyków. Co ciekawe, u pewnej grupy osób z ciężkim przebiegiem choroby COVID-19 nie pojawił się żaden $z$ uznanych czynników

Tabela 1. Geny archaiczne pochodzące od Neandertalczyków oraz Denisowian wraz z pełnionymi przez nie funkcjami.

\begin{tabular}{|c|c|c|c|c|}
\hline Wpływ introgresji & Gen & $\begin{array}{l}\text { Pełna nazwa kodo- } \\
\text { wanego białka }\end{array}$ & $\begin{array}{l}\text { Znaczenie wariantów } \\
\text { archaicznych }\end{array}$ & Literatura \\
\hline \multirow[t]{2}{*}{$\begin{array}{l}\text { Adaptacja do du- } \\
\text { żych wysokości }\end{array}$} & BNC2 & $\begin{array}{l}\text { EGL-9 Family Hypo- } \\
\text { xia Inducible Factor } \\
1\end{array}$ & \multirow{2}{*}{$\begin{array}{l}\text { Przystosowanie do du- } \\
\text { żych wysokości, małej } \\
\text { ilości tlenu w powietrzu } \\
\text { i niskiego ciśnienia }\end{array}$} & \multirow{2}{*}{$\begin{array}{l}\text { HUERTA-SÁN- } \\
\text { CHEZ i współaut. } \\
2014 \text {, HUER- } \\
\text { TA-SÁNCHEZ i } \\
\text { CASEY 2015, } \\
\text { HACKINGER i } \\
\text { Współaut. 2016, } \\
\text { ZHANG i współ- } \\
\text { aut. } 2020\end{array}$} \\
\hline & EPAS 1 & $\begin{array}{l}\text { Endothelial PAS Do- } \\
\text { main Protein } 1\end{array}$ & & \\
\hline \multirow[t]{2}{*}{ Cukrzyca typu 2} & SLC16A11 & $\begin{array}{l}\text { Solute Carrier Fami- } \\
\text { ly } 16 \text { Member } 11\end{array}$ & \multirow{2}{*}{$\begin{array}{l}\text { Zwiększenie ryzyka za- } \\
\text { chorowania na cukrzycę } \\
\text { typu } 2\end{array}$} & \multirow{2}{*}{$\begin{array}{l}\text { THE Sigma TYPE } \\
2 \text { DIABETES CON- } \\
\text { SORTIUM } 2014\end{array}$} \\
\hline & SLC16A13 & $\begin{array}{l}\text { Solute Carrier Fami- } \\
\text { ly } 16 \text { Member } 13\end{array}$ & & \\
\hline \multirow[t]{3}{*}{ Pigmentacja } & HYAL2 & Hyaluronidase 2 & $\begin{array}{l}\text { Odpowiedź komórkowa } \\
\text { na promieniowanie UV }\end{array}$ & $\begin{array}{l}\text { DING i współaut. } \\
2014\end{array}$ \\
\hline & $\mathrm{BNC} 2$ & Basonuclin 2 & $\begin{array}{l}\text { Pigmentacja i występo- } \\
\text { wanie piegów }\end{array}$ & $\begin{array}{l}\text { JACOBS i współ- } \\
\text { aut. } 2013\end{array}$ \\
\hline & MC1R & $\begin{array}{l}\text { Malanocortin } 1 \text { Re- } \\
\text { ceptor }\end{array}$ & $\begin{array}{l}\text { Wystepowanie rudego } \\
\text { koloru włosów, jasnego } \\
\text { koloru skóry i piegów }\end{array}$ & $\begin{array}{l}\text { Valverde i } \\
\text { współaut. } 1996\end{array}$ \\
\hline $\begin{array}{l}\text { Mięśnie szkiele- } \\
\text { towe }\end{array}$ & DMD & Dystrophin & $\begin{array}{l}\text { Stabilizacja błony ko- } \\
\text { mórkowej w komórkach } \\
\text { mieśniowych, efekt ha- } \\
\text { plotypu B006 nie został } \\
\text { jeszcze poznany }\end{array}$ & $\begin{array}{l}\text { ZIETKIEWICZ i } \\
\text { współaut. } 2003\end{array}$ \\
\hline
\end{tabular}


Odporność wrodzona
Oligoadenylate Synthetase 1
Zwiększenie ekspresji $\mathrm{w}$ podskórnej tkance tłuszczowej i skórze wystawionej na działanie promieni słonecznych, zwiększenie poziomu cholesterolu

\begin{tabular}{ll}
\hline OAS2 & $\begin{array}{l}\text { Oligoadenylate Syn- } \\
\text { thetase } 2\end{array}$
\end{tabular}

Zwiększenie ekspresji w tarczycy, zwiększa procesy zapalne $\mathrm{w}$ raku tarczycy

\begin{tabular}{ll}
\hline OAS3 & $\begin{array}{l}\text { Oligoadenylate Syn- } \\
\text { thetase 3 }\end{array}$ \\
\hline ERAP2 & $\begin{array}{l}\text { Endoplasmic Reticu- } \\
\text { lum Aminopeptidase } \\
2\end{array}$ \\
\hline ZNF365D & $\begin{array}{l}\text { Zinc Finger Protein } \\
365\end{array}$
\end{tabular}

CCR1 C-C Motif Chemoki- Aktywacja migracji ma-
ne Receptor $1 \quad$ krofagów i komórek NK do miejsca infekcji, stanu zapalnego

\begin{tabular}{ll}
\hline HLA-DQA1 & $\begin{array}{l}\text { Human Leukocyte } \\
\text { Antygen Complex } \\
\text { DQA 1 }\end{array}$ \\
\hline IL18RAP & $\begin{array}{l}\text { Interleukin 18 Re- } \\
\text { ceptor Accessory }\end{array}$ \\
& $\begin{array}{l}\text { Protein } \\
\text { SH2B3 }\end{array}$ \\
& $\begin{array}{l}\text { SH2B Adaptor Pro- } \\
\text { tein 3 }\end{array}$
\end{tabular}

IL12A Interleukin 12a Zwiększenie podatności

TLR1 - $10 \quad$ Toll Like Receptor
na celiakie

Aktywacja prowadzi do uwolnienia czynników prozapalnych, ważnych w odpowiedzi antywirusowej

Koagulacja krwi i SELP
procesy zapalne

Selectin P

Zwiększenie ekspresji w przypadku wystapienia

Zaburzenia prawidłowej budowy i liczebności elementów morfotycznych krwi
MENDEZ i współaut. 2013

Dolgova i LaO 2018

\begin{tabular}{|c|c|c|c|c|}
\hline procesy zapalne & & & $\begin{array}{l}\text { i płytek krwi do po- } \\
\text { wierzchni komórek } \\
\text { śródbłonka, zwiększenie } \\
\text { ryzyka wystapienia żyl- } \\
\text { nej choroby zakrzepowo } \\
\text { - zatorowej }\end{array}$ & 2012 \\
\hline $\begin{array}{l}\text { Zaburzenia odży- } \\
\text { wiania }\end{array}$ & SLC35F3 & $\begin{array}{l}\text { Solute Carrier Fami- } \\
\text { ly } 35 \text { Member F3 }\end{array}$ & $\begin{array}{l}\text { Zwiększenie objawów } \\
\text { niedożywienia }\end{array}$ & $\begin{array}{l}\text { SimONTI i współ- } \\
\text { aut. } 2016\end{array}$ \\
\hline $\begin{array}{l}\text { Zaburzenia funk- } \\
\text { cjonowania ukła- } \\
\text { du moczowego }\end{array}$ & STIM 1 & $\begin{array}{l}\text { Stromal Interaction } \\
\text { Molecule } 1\end{array}$ & $\begin{array}{l}\text { Zaburzenia funkcjono- } \\
\text { wania przewodów mo- } \\
\text { czowych, nietrzymanie } \\
\text { moczu, ból pęcherza } \\
\text { moczowego }\end{array}$ & $\begin{array}{l}\text { SimONTI i współ- } \\
\text { aut. } 2016\end{array}$ \\
\hline $\begin{array}{l}\text { Uzależnienie od } \\
\text { nikotyny }\end{array}$ & SLC6A11 & $\begin{array}{l}\text { Solute Carrier Fami- } \\
\text { ly } 6 \text { Member } 11\end{array}$ & $\begin{array}{l}\text { Zakłócenie sygnalizacji } \\
\text { GABAergicznej, zwięk- } \\
\text { szone ryzyko uzależnie- } \\
\text { nia od nikotyny }\end{array}$ & $\begin{array}{l}\text { PICKERING i } \\
\text { współaut. } 2008\end{array}$ \\
\hline
\end{tabular}




\begin{tabular}{|c|c|c|c|c|}
\hline $\begin{array}{l}\text { Rak szyjki maci- } \\
\text { cy spowodowany } \\
\text { zakażeniem wiru- } \\
\text { sem HPV }\end{array}$ & $\begin{array}{l}\text { HLA B*07:02, } \\
\mathrm{C}^{*} 07: 02\end{array}$ & $\begin{array}{l}\text { Human Leukocyte } \\
\text { Antygen B, C class }\end{array}$ & $\begin{array}{l}\text { Zwiększone ryzyko za- } \\
\text { chorowania na raka } \\
\text { szyjki macicy w wyniku } \\
\text { zakażenia wirusem HPV }\end{array}$ & $\begin{array}{l}\text { CHEN i współ- } \\
\text { aut. } 2018\end{array}$ \\
\hline $\begin{array}{l}\text { Odpowiedź im- } \\
\text { munologiczna na } \\
\text { zakażenie wiru- } \\
\text { sem HIV }\end{array}$ & HLA & $\begin{array}{l}\text { Human Leukocyte } \\
\text { Antygen }\end{array}$ & $\begin{array}{l}\text { W przypadku zakażenia } \\
\text { wirusem HIV typu B } \\
\text { wzmaga działanie syste- } \\
\text { mu odpornościowego }\end{array}$ & $\begin{array}{l}\text { KIST i współaut. } \\
2020\end{array}$ \\
\hline
\end{tabular}

ryzyka. Genetycy jak zwykle zadali pytanie, na ile same geny decyduja o obserwowanych osobniczych i populacyjnych różnicach w stopniu narażenia na zakażenie i ciężki przebieg COVID-19. Badania nad SARS-CoV-2 szybko wykazały, że podobnie jak w przypadku SARS-CoV-1, receptorem umożliwiajaccym infekcję komórek gospodarza jest zwiąany $z$ błona komórkowa enzym ACE2 (HoffmAnN i współaut. 2020). Duża liczba cząsteczek receptora ACE2 występuje na powierzchni komórek pęcherzykowych typu 2, które stanowia od 10-15\% komórek płuc. Ekspresja genu ACE2 obserwowana jest również w komórkach pęcherzykowych typu 1, komórkach nabłonka dróg oddechowych, fibroblastach, komórkach śródbłonka i makrofagach, choć na niższym poziomie, który dodatkowo wykazuje zmienność osobniczą. Rozmieszczenie receptora ACE2 uzasadnia drogę zakażenia i główną lokalizację wirusa SARS-CoV-2 na poziomie komórkowym (CASTRANOVA i współaut. 1988, BENETTI i współaut. 2020). Zasadnym stało się pytanie, na ile zmienność sekwencji genu ACE2 może narażać na zakażenie wirusem i na przebieg COVID-19. Znane sa trzy częste $i$ ponad dwadzieścia rzadkich wariantów tego genu zmieniajacych sekwencję białka. Obserwowane międzypopulacyjne różnice częstości wariantów na świecie i analiza ich wpływu na funkcję receptora nie dały jednak jednoznacznej odpowiedzi na pytanie o różnice w podatności na zakażenie wirusem SARS-CoV-2. Można jedynie spekulować, że różnice w sekwencji białka ACE2 może wpływać na konformację receptora i częściowo wyjaśniać obserwowane międzyosobnicze różnice w przebiegu choroby (BENETTI i współaut. 2020, KHAYAT i współaut. 2021). Badaniami objęto również wspomniany wcześniej kompleks zgodności tkankowej HLA, który jest kluczowy dla odporności adaptacyjnej u człowieka. Niektóre badania sugeruja duże znaczenie niektórych wariantów genów układu HLA dla przebiegu choroby COVID-19 (MIGLIORINI i współaut. 2021, VishnUBHOTLA i współaut. 2021). Ograniczona skala analiz i bardzo wysoka zmienność genów HLA nakazuje ostrożność w interpretacji danych, ale warto zauważyć, że trzy warianty genów HLA kla- sy I (zaangażowanej w odporność przeciwwirusową) znacznie częściej występowały u osób o ciężkim i krytycznym przebiegu choroby niż u osób przechodzących COVID-19 w sposób umiarkowany i łagodny (WANG F. i współaut. 2020, KHOR i współaut. 2021, PAIRO-CASTINEIRA i współaut. 2021). Możliwe, że wariant $A^{*} 11: 01$ proponowany jako potencjalny marker ciężkiego przebiegu choroby COVID-19 (WARREN i BIROL 2020) jest obecny w genomie współczesnych ludzi na skutek introgresji fragmentu DNA pochodzenia denisowiańskiego. Drugi $z$ niebezpiecznych wariantów, $B * 51: 01$ ma $z$ kolei sekwencję bardzo podobna do wariantu zidentyfikowanego w genomach neandertalskich (ABI-RACHED i współaut. 2011). Argumenty za archaicznym pochodzeniem przedstawiono również dla genów CCR1 i TLR110 (Tabela 2). Ze zgromadzonych danych wynika, że moga mieć negatywny wpływ na przebieg COVID-19. Receptor CCR1 jest odpowiedzialny za aktywację migracji makrofagów i komórek NK (ang. natural killers) do miejsca infekcji, a więc wpływa za rozwój stanu zapalnego. Istotny dla przebiegu COVID-19 może być poziom ekspresji genu kodujacego receptor. Wyższy poziom CCR1 zaobserwowano w umiarkowanie ciężkich i ciężkich przypadkach COVID-19 w porównaniu do pacjentów o łagodniejszym przebiegu choroby. Zasugerowano, że farmakologiczna inhibicja tego receptora może hamować hiperaktywację układu odpornościowego i poprawić rokowania w krytycznych przypadkach COVID-19 (STIKKER i współaut. 2021). Rodzina receptorów Toll-podobnych (TLR), których funkcja jest alarmowanie układu immunologicznego o infekcji, może być istotna zarówno w początkowym stadium choroby COVID-19, jak i w późniejszym rozwoju ciężkich objawów zakażenia, w tym ostrej niewydolności oddechowej. Szczególnie istotny jest TLR7, który ma zdolność rozpoznania wirusowego jednoniciowego RNA, w tym SARS-CoV-2. Aktywacja receptorów prowadzi do uwolnienia czynników prozapalnych, ważnych w odpowiedzi antywirusowej (DOLGOVA i LAO 2018, ANASTASSOPOULOU i współaut. 2020, ONOFRIO i współaut. 2020, VAN DER MADE i współaut. 2020). 
Tabela 2. Geny archaiczne pochodzące od Neandertalczyków oraz Denisowian mające wpływ na przebieg choroby COVID-19 wraz $z$ pełnionymi przez nie funkcjami oraz częstością występowania we współczesnych populacjach ludzkich.

\begin{tabular}{|c|c|c|c|c|c|}
\hline $\begin{array}{l}\text { Chromo- } \\
\text { som }\end{array}$ & Gen & $\begin{array}{l}\text { Pełna nazwa ko- } \\
\text { dowanego białka }\end{array}$ & $\begin{array}{l}\text { Znaczenie wariantów ar- } \\
\text { chaicznych }\end{array}$ & $\begin{array}{l}\text { Częstość w popu- } \\
\text { lacjach }\end{array}$ & Literatura \\
\hline 2 & DPP4 & $\begin{array}{l}\text { Dipeptyl Peptida- } \\
\text { se } 4\end{array}$ & $\begin{array}{l}\text { Kodowanie enzymu } \\
\text { spełniającego funkcję } \\
\text { receptora dla SARS- } \\
\text {-CoV-2, dwukrotne } \\
\text { zwiększenie ryzyka cięż- } \\
\text { kiego przebiegu choroby } \\
\text { COVID-19 }\end{array}$ & $\begin{array}{l}\text { Obecny u około } \\
\text { 1\% Europejczyków, } \\
2.5 \% \text { mieszkańców } \\
\text { Południowej Azji, } \\
4 \% \text { Wschodniej } \\
\text { Azji, 0.7\% obu } \\
\text { Ameryk, nieobecny } \\
\text { w Afryce na połu- } \\
\text { dnie od Sahary }\end{array}$ & $\begin{array}{l}\text { ZEBERG } \\
\text { i PÄÄBO } \\
2020\end{array}$ \\
\hline \multirow[t]{7}{*}{3} & SLC6A20 & $\begin{array}{l}\text { Solute Carrier } \\
\text { Family } 6 \text { Member } \\
20\end{array}$ & \multirow{6}{*}{$\begin{array}{l}\text { Aktywacja odpowie- } \\
\text { dzi immunologicznej, } \\
\text { zwiększenie napływu } \\
\text { limfocytów, czynników } \\
\text { komórek prezentujących } \\
\text { antygeny oraz komórek } \\
\text { NK do miejsca występo- } \\
\text { wania stanu zapalnego, } \\
\text { SLC6A20 koduje trans- } \\
\text { porter proliny, który } \\
\text { wzmaga wchodzenie } \\
\text { wirusa SARS-CoV-2 do } \\
\text { komórek gospodarza } \\
\text { dzięki ACE2. U pa- } \\
\text { cjentów posiadających } \\
\text { zaintrodukowane SNPy } \\
\text { zaobserwowano niewy- } \\
\text { dolność płuc. }\end{array}$} & \multirow{6}{*}{$\begin{array}{l}\text { SNP obecne u oko- } \\
\text { ło } 65 \% \text { mieszkań- } \\
\text { ców Południowej } \\
\text { Azji, } 16 \% \text { miesz- } \\
\text { kańców Europy, } \\
\text { prawie w ogóle } \\
\text { nie pojawia się we } \\
\text { Wschodniej Azji }\end{array}$} & \multirow{6}{*}{$\begin{array}{l}\text { THE SE- } \\
\text { VERE } \\
\text { COVID-19 } \\
\text { GWAS } \\
\text { GROUP } \\
\text { 2020, LEE } \\
\text { i współ- } \\
\text { aut. } 2021 \\
\text { ZEBERG } \\
\text { i PÄÄBO } \\
\text { 2020 }\end{array}$} \\
\hline & LZTFL1 & $\begin{array}{l}\text { Leucine Zipper } \\
\text { Transcription } \\
\text { Factor Like } 1\end{array}$ & & & \\
\hline & CCR9 & $\begin{array}{l}\text { C-C Motif Che- } \\
\text { mokine Receptor } \\
9\end{array}$ & & & \\
\hline & FYCO1 & $\begin{array}{l}\text { FYVE and Coiled- } \\
\text {-Coin Domain } \\
\text { Autophagy Ada- } \\
\text { ptor } 1\end{array}$ & & & \\
\hline & CXCR6 & $\begin{array}{l}\text { C-X-C Chemokine } \\
\text { Receptor } 6\end{array}$ & & & \\
\hline & XCR1 & $\begin{array}{l}\text { Chemokine XC } \\
\text { Receptor } 1\end{array}$ & & & \\
\hline & CCR1 & $\begin{array}{l}\text { C-C Chemokine } \\
\text { Receptor Type } 1\end{array}$ & $\begin{array}{l}\text { Aktywację migracji ma- } \\
\text { krofagów i komórek NK } \\
\text { (ang. Natural Killers) } \\
\text { do miejsca infekcji, } \\
\text { wpływ na rozwój stanu } \\
\text { zapalnego. Wyższy po- } \\
\text { ziom CCR1 zaobserwo- } \\
\text { wano w umiarkowanie } \\
\text { ciężkich i ciężkich przy- } \\
\text { padkach COVID-19. }\end{array}$ & $\begin{array}{l}\text { SNP rs3181080 } \\
\text { A>T oraz SNP } \\
\text { rs34919616 G>A } \\
\text { obecne u } 8,8 \% \\
\text { Europejczyków, } \\
1,1 \% \text { Afrykańczy- } \\
\text { ków, 3,6 \% Azja- } \\
\text { tów }\end{array}$ & $\begin{array}{l}\text { STIKKER i } \\
\text { współaut. } \\
2021\end{array}$ \\
\hline 6 & HLA & $\begin{array}{l}\text { Human Leukocyte } \\
\text { Antigen }\end{array}$ & $\begin{array}{l}\text { Warianty } A^{*} 11: 01 \mathrm{i} \\
\mathrm{B}^{\star} 51: 01 \text { stanowia po- } \\
\text { tencjalne markery cięż- } \\
\text { kiego przebiegu choroby }\end{array}$ & $\begin{array}{l}\text { A*11:01 obecny } \\
\text { głównie w popu- } \\
\text { lacjach Azji od } \\
17.7 \%-61.3 \% \text {, w } \\
\text { Europie od } 11,4 \% \\
\text { - 15\%, B*51:01 } \\
\text { obecny od } 5,2 \% \text { - } \\
\text { 14,5\%, w Azji }\end{array}$ & $\begin{array}{l}\text { KHOR i } \\
\text { współaut. } \\
2021 \text {, } \\
\text { WANG i } \\
\text { współaut. } \\
2020\end{array}$ \\
\hline
\end{tabular}




\begin{tabular}{|c|c|c|c|c|c|}
\hline 12 & $\begin{array}{l}\text { OAS1, } \\
\text { OAS2, } \\
\text { OAS3 }\end{array}$ & $\begin{array}{l}\text { Oligoadenylate } \\
\text { Synthetase } 1 \text {, } \\
2,3\end{array}$ & $\begin{array}{l}\text { Kodowanie białek pro- } \\
\text { dukujących enzymy } \\
\text { degradujace wewnattrz- } \\
\text { komórkowe dwuniciowe } \\
\text { RNA, aktywacja mecha- } \\
\text { nizmów przeciwwiruso- } \\
\text { wych w zainfekowanych } \\
\text { komórkach gospodarza, } \\
\text { redukcja ciężkiego prze- } \\
\text { biegu COVID-19 o około } \\
22 \%\end{array}$ & $\begin{array}{l}\text { 25-30\% w popula- } \\
\text { cjach Eurazji, ni- } \\
\text { ska częstotliwość w } \\
\text { populacjach Ame- } \\
\text { ryki, nie występuje } \\
\text { w Afryce na połu- } \\
\text { dnie od Sahary }\end{array}$ & $\begin{array}{l}\text { ZEBERG } \\
\text { i PÄÄBO } \\
2021 \\
\text { ZHOU i } \\
\text { współaut. } \\
2021\end{array}$ \\
\hline \multirow[t]{2}{*}{$X$} & TLR7 & $\begin{array}{l}\text { Toll - Like Recep- } \\
\text { tor } 7\end{array}$ & $\begin{array}{l}\text { Posiada zdolność rozpo- } \\
\text { znania wirusowego jed- } \\
\text { noniciowego RNA, } \\
\text { w tym SARS-CoV-2. } \\
\text { Aktywacja receptorów } \\
\text { prowadzi do uwolnienia } \\
\text { czynników prozapal- } \\
\text { nych, ważnych w odpo- } \\
\text { wiedzi antywirusowej. }\end{array}$ & $\begin{array}{l}\text { Delecje drastycznie } \\
\text { zwiększajace ciężki } \\
\text { przebieg COVID-19 } \\
\text { odkryte u pojedyn- } \\
\text { czych pacjentów z } \\
\text { Danii, wymagane } \\
\text { dalsze badania }\end{array}$ & $\begin{array}{l}\text { ANAS- } \\
\text { TASSOPOU- } \\
\text { LOU i } \\
\text { współaut. } \\
2020 \text {, } \\
\text { DOLGOVA i } \\
\text { LAO 2018, } \\
\text { ONOFRIO i } \\
\text { współaut. } \\
\text { 2020, VAN } \\
\text { DER MADE } \\
\text { i współaut. } \\
2020\end{array}$ \\
\hline & ACE2 & $\begin{array}{l}\text { Angiotensin } \\
\text { Converting } \\
\text { Enzyme } 2\end{array}$ & $\begin{array}{l}\text { Wpływ na zwiększenie } \\
\text { prawdopodobieństwa za- } \\
\text { każenia wirusem SARS- } \\
\text {-CoV-2 poprzez umoż- } \\
\text { liwienie wejścia wirusa } \\
\text { do komórki gospodarza }\end{array}$ & $\begin{array}{l}\text { W populacji Eu- } \\
\text { ropejskiej wariant } \\
\text { rs41303171 wystę- } \\
\text { puje u około } 2 \% \\
\text { mieszkańców, nie- } \\
\text { obecny u Azjatów }\end{array}$ & $\begin{array}{l}\text { ANAS- } \\
\text { TASSOPOU- } \\
\text { LOU i } \\
\text { współaut. } \\
2020 \text {, } \\
\text { BENETTI } \\
\text { i współ- } \\
\text { aut. 2020, } \\
\text { KHAYAT i } \\
\text { współaut. } \\
2021\end{array}$ \\
\hline
\end{tabular}

Najszerszych danych na temat możliwej roli genów w odpowiedzi na SARS-CoV-2 dostarczyły badania asocjacyjne całego genomu GWAS ${ }^{1}$, które pozwoliły na identyfikację w genomie człowieka szeregu genów, które moga decydować o zróżnicowaniu odpowiedzi na SARS-CoV-2 (THE SEVERE COVID-19 GWAS GROUP 2020, PAIRO-CASTINEIRA i współaut. 2021). Uzyskane wyniki sa bardzo ciekawe. Badania przeprowadzone na populacjach włoskiej i hiszpańskiej zdaja się potwierdzać wcześniejsze obserwacje o zna-

\footnotetext{
${ }^{1}$ Badania asocjacyjne całego genomu (ang. genome-wide association studies, GWAS) - maja na celu identyfikacje asocjacji genotypów $z$ fenotypami poprzez badanie różnic w częstości wariantów DNA pomiędzy osobami, które maja wspólne pochodzenie populacyjne, ale różnią się fenotypowo. Technicznie polegaja na testowaniu setek tysieccy wariantów DNA w genomach wielu niespokrewnionych osób, w celu wykrycia tych, które sa statystycznie powiazane $z$ określona cechą lub chorobą.
}

czeniu grupy krwi w przebiegu COVID-19 i ochronnej roli grupy krwi $0 \mathrm{w}$ tym względzie. W ujawnionym przez badania regionie 9q34.2 genomu znajduja się bowiem geny odpowiedzialne za kodowanie grup krwi w układzie ABO (THE SEVERE COVID-19 GWAS GROUP 2020). Z kolei badania przeprowadzone $z$ uwzględnieniem próbek zgromadzonych w biobanku brytyjskim ujawniły znaczenie genów związanych $z$ kluczowymi mechanizmami obrony przeciwwirusowej gospodarza i mediatorami reakcji zapalnej. Istotny sygnał wykryto w regionie 19p13.3, w którym znajduje się gen DPP9, w regionie 12q24.13, gdzie zlokalizowane sa geny kodujące przeciwwirusowe aktywatory enzymów restrykcyjnych (OAS1, OAS2, OAS3) oraz w regionie 21q22.1, gdzie znajduje się gen receptora interferonu IFNAR2 (PAIRO-CASTINEIRA i współaut. 2021). Co ciekawe, oba bada- 
nia potwierdziły istotne znaczenie regionu 3 p21.3 o długości niemal 50 tysięcy par zasad dla ciężkiego przebiegu COVID-19. Zestawienie genów pochodzenia archaicznego zwiazanych przebiegiem COVID-19 znajduje się w Tabeli 2.

Bardziej szczegółowo opiszemy jeszcze trzy istotne loci genetyczne zaangażowane w kształtowanie reakcji organizmu na SARS-CoV-2 i przebieg COVID-19, które do genomu człowieka współczesnego trafiły na skutek przepływu genów od krewnych człowieka współczesnego, przed dziesiątkami tysięcy lat. Pierwszy, to haplotyp $\mathrm{w}$ regionie $3 \mathrm{p} 21.3$, który jest obecnie uznawany za jeden $z$ głównych czynników genetycznych ciężkiego przebiegu COVID-19. Co najmniej jedna kopię niebezpiecznego wariantu DNA posiada 50\% mieszkańców Azji Południowej i 16\% mieszkańców Europy (ZEBERG i PÄÄBO 2020). Nie ma jasności, który gen pochodzenia neandertalskiego $\mathrm{w}$ tym regionie zwiększa ryzyko ciężkiego przebiegu COVID-19, nie wiadomo też, na ile efekt ten jest specyficzny dla SARS-CoV-2, szerszej grupy koronawirusów czy ogólnie patogenów wirusowych. Dane sa jednak bardzo przekonujace, w regionie tym znajdują się geny SLC6A20, LZTFL1, CCR9, FYCO1, CXCR6 i XCR1 zwiazane z aktywacja odpowiedzi immunologicznej i patogeneza, napływem limfocytów, czynników komórek prezentujacych antygeny oraz komórek NK. Oszacowano, że posiadanie wariantu GA (insercja jednego nukleotydu w pozycji rs11385942) zwiazane jest ze zwiększeniem ekspresji genów SLC6A2O i LZTFL1 oraz zmniejszeniem ekspresji genu CXCR6. Wyższa częstość tej insercji zaobserwowano u pacjentów wymagających dodatkowego, mechanicznego wspomagania oddychania, niż u pacjentów okazjonalnie suplementownych tlenem (THE SEVERE COVID-19 GWAS GROUP 2020). Warto zauważyć, że SLC6A20 koduje transporter proliny, który wchodzi w bezpośrednia interakcję $z$ receptorem ACE2, co za tym idzie wspomaga penetrację wirusa SARS-CoV-2 do wnętrza komórek gospodarza (LEE i współaut. 2021). Nie jest jasne, dlaczego neandertalski haplotyp w regionie 3p21.3 jest niekorzystny w przypadku choroby COVID-19. $Z$ przeprowadzonych analiz wynika, że mógł on być faworyzowany przez dobór naturalny w niektórych populacjach azjatyckich. Być może chronił przed innymi patogenami obecnymi na tych terenach. Nie można też wykluczyć, że wariant ten był skuteczniej usuwany przez dobór oczyszczający w populacjach, w których jest on obecnie słabiej reprezentowany (ZEBERG i PÄÄBO 2021). Negatywny wpływ introgresji neandertalskiej na przebieg COVID-19 równoważy nieco wariant, który również pocho- dzi od Neandertalczyków, obecny w regionie 12q24.13. Korzystny haplotyp zawiera sekwencje trzech wspominanych już wcześniej genów OAS1, OAS2 oraz OAS3, które kodują białka produkujace enzymy degradujace wewnątrzkomórkowe dwuniciowe RNA i aktywuja inne mechanizmy przeciwwirusowe w zainfekowanych komórkach (ZEBERG i PÄÄBO 2021, ZHOU i współaut. 2021). Zwiazek Z ciężkim przebiegiem COVID-19 został odkryty w badaniu GWAS przeprowadzonym na populacji zrekrutowanej przez biobank brytyjski, ale ten efekt introgresji neandertalskiej nie może być uznany za specyficzny dla SARS-CoV-2 (PEREIRA i współaut. 2021). Jak wcześniej wspomniano, wykazano znaczenie archaicznego wariantu genu OAS1 w walce $z$ zakażeniem flawiwirusami, w tym wirusem dengi (AlAGARASU i współaut. 2013) i wirusem goraczki Zachodniego Nilu (LIM i współaut. 2009). Okazuje się, że haplotyp pochodzący oryginalnie od Neandertalczyków - rs10774671-G, redukuje o około $22 \%$ ryzyko ciężkiego przebiegu choroby COVID-19. Występuje on $z$ częstościa $25-30 \%$ populacji Eurazji, jest znacznie rzadszy w Amerykach i zgodnie $z$ oczekiwaniami, zupełnie nieobecny w populacjach Afrykańskich zamieszkujących tereny znajdujace się na południe od Sahary.

DPP4 to ostatni gen pochodzenia neandertalskiego, który przedstawiamy bardziej szczegółowo. Wariant archaiczny ma negatywny wpływ na przebieg COVID-19. Gen DPP4 zlokalizowany jest na chromosomie 2 i koduje enzym, który służy jako receptor dla wcześniej odkrytego koronawirusa MERS-CoV. Gen DPP4 wzięto pod lupę w kontekście COVID-19 w zwiąku $z$ wynikami badań sugerującymi, że pełni on również funkcję receptora dla SARS-CoV-2. Wprawdzie badania GWAS nie potwierdziły znaczenia tego genu dla przebiegu COVID-19, ale wykryły znaczenie genu DPP9, który ma wspólne pochodzenie ewolucyjne $z$ genem DPP4 (Li i współaut. 2020, PEREIRA i współaut. 2021). Jednak $z$ analizy przeprowadzonej przez konsorcjum badajace wpływ genów gospodarza na przebieg choroby wynika, że ryzyko ciężkiego przebiegu COVID-19 rośnie dwukrotnie wraz $z$ posiadaniem archaicznego wariantu genu DPP4 (THE COVID-19 Host Genetics InITIATIVE 2020). Wariant ten obecny jest u około 1\% Europejczyków, około 2,5\% mieszkańców Południowej Azji, 4\% mieszkańców Wschodniej Azji, około 0.7\% mieszkańców Ameryk i nie występuje w populacjach zamieszkujących Afrykę Subsaharyjską (ZEBERG i PÄÄBO 2020). Analiza dostępnych genomów neandertalskich wskazuje, że warianty ryzyka ciężkiego przebiegu COVID-19 w obu tych regionach genomu 
były bardzo częste u Neandertalczyków, co dziśs decydowałoby o ich znacznie większej wrażliwości na infekcję SARS-CoV-2 niż ludzi współczesnych. Być może zatem do wymarcia tego gatunku rzeczywiście przyczyniły się właśnie epidemie, jak to sugerowano wcześniej (ZEBERG i PÄÄBO 2020).

\section{PODSUMOWANIE}

$\mathrm{Na}$ pandemię COVID-19 bez watpienia można spojrzeć $z$ perspektywy starcia wirusa $z$ układem odpornościowym i behawiorem człowieka, ale także $z$ nowoczesną nauką. Epidemie nie sa niczym nowym, prawdopodobnie kształtowały historię ewolucyjna wielu gatunków zamieszkujacych Ziemię, również tych wymarłych, być może częściowo na skutek braku skutecznej obrony przed patogenami (SULLIVAN i współaut. 2017, GREENBAUM i współaut. 2019). Epidemie wielokrotnie dziesiątkowały populację człowieka współczesnego (PIRET i BOIVIN 2021). Mobilność człowieka w XXI w. sprawia, że rozwój pandemii jest szczególnie ułatwiony, a przez to wpływ niebezpiecznego patogenu ma błyskawicznie wymiar cywilizacyjny. Jednocześnie nauka może, jak nigdy dotąd, pomagać w podejmowaniu świadomych działań, które ograniczają skutki pandemii i pomagaja $w$ walce $z$ patogenem. W przypadku COVID-19 nauka pozwoliła na wyciągnięcie wniosków na przyszłość, w której nowe wirusy moga znowu zagrozić człowiekowi. Szczegółowe badania, które prowadzono w trakcie pandemii COVID-19, pozwoliły na identyfikację genów istotnych $z$ punktu widzenia przebiegu tej choroby. Okazuje się, że również spojrzenie w przeszłość, która zapisana jest $\mathrm{w}$ naszych genomach, może być pomocne $\mathrm{w}$ walce $\mathrm{z}$ patogenami. Niektóre $\mathrm{Z}$ wariantów tych genów w genomie człowieka współczesnego znalazły się na skutek introgresji. Co ciekawe, $z$ wstepnych analiz wynika, że większość archaicznych wariantów genów wpływa na pogorszenie przebiegu zakażenia SARS-CoV-2, zwiększając tym samym prawdopodobieństwo wystapienia poważnych powikłań. Jednocześnie, statystyki dotyczace zapadalności na COVID-19 pokazują, że najwięcej przypadków zachorowań miało miejsce w Europie, w Ameryce Południowej i Azji, a więc w populacjach, które odziedziczyły warianty archaiczne. W Afryce, gdzie w puli genów niemal nie występują sekwencje pochodzące od Neandertalczyków i Denisowian, zachorowalność na COVID-19 jest niższa, a przebieg choroby łagodniejszy (ZAHID i PERNA 2021). Sugeruje to istotny wpływ obecności wariantów genów Neandertalskich i Denisowiańskich na rozwój epidemii, choć wniosek ten należy traktować ostrożnie. Z badań wynika, że zachowane w naszych genomach segmenty pochodzenia neandertalskiego można wykorzystać do wykrywania zamierzchłych epidemii (ENARD i PETROV 2018, WANG F. i współaut. 2020, SouILMI i współaut. 2021). Dalsze badania moga wyjaśnić znaczenie archaicznych wariantów genetycznych obecnych w genomie człowieka współczesnego $\mathrm{w}$ odniesieniu do pandemii COVID-19, epidemii, które miały miejsce w przeszłości oraz pozwolić na lepsze oszacowanie ryzyka w przyszłych epidemiach.

$$
\text { Streszczenie }
$$

Badania paleogenetyczne $z$ zastosowaniem wysokoprzepustowego sekwencjonowania DNA umożliwiły ujawnienie genów wymarłych gatunków ludzkich w genomach człowieka współczesnego. Jest to dowód krzyżowania się naszych przodków $z$ człowiekiem neandertalskim i denisowiańskim na terenach Azji i Europy. Co więcej, może to świadczyć o korzyściach adaptacyjnych jakie człowiek współczesny, zajmujacy nowe obszary geograficzne, odniósł na skutek pozyskania nowych wariantów genów od archaicznych gatunków. Jednym $z$ istotnych wyzwań, na jakie nasi przodkowie natrafili po opuszczeniu Afryki, były nowe patogeny, a w szczególności wirusy. $Z$ przeprowadzonej analizy współczesnych genomów wynika, że w walce $z$ nimi mogły pomóc geny odziedziczone od naszych wymarłych krewnych, kodujace białka układu odpornościowego i białka odpowiedzialne za ochronę przed zakażeniami wirusowymi. Okazuje się, że geny obecne w genomie człowieka dzięki introgresji mają również znaczenie w starciu $z$ wirusem SARS-CoV-2, a w szczególności wpływają na przebieg choroby COVID-19. Co ciekawe, niektóre $z$ nich, jak SLC6A20, LZTFL1, XCR1, czy DPP4, moga przyczyniać się do zwiększenia ryzyka ciężkiego przebiegu choroby, a inne, jak OAS1, OAS2 i OAS3, ryzyko to redukuja. Dalsze badania moga wyjaśnić znaczenie tych wariantów genetycznych w odniesieniu do przeszłych zdarzeń, które doprowadziły do zwiększenia ich częstości w genomach współczesnych ludzi. Możliwe, że to właśnie wirusy były istotnym czynnikiem doboru, który doprowadził do obecności genów wymarłych gatunków ludzkich w genomach człowieka współczesnego, a geny te stanowia świadectwo przeszłych epidemii.

\section{LITERATURA}

ABI-RACHED L., JOBIN M. J., KULKARNI S., McWhinnie A., DAlva K., Gragert L., BABRZADEH F., GHARIZADEH B., LUO M., PlumMER F. A., KIMANI J., CARRINGTON M., MidDleTON D., RAJALINGAM R. i współaut., 2011. The shaping of modern human immune systems by multiregional admixture with archaic humans. Science 334, 89-94.

Alagarasu K., Honap T., Damle I. M., Mulay A. P., SHAH P. S., CECILIA D., 2013. Polymorphisms in the oligoadenylate synthetase gene cluster and its association with clinical outcomes of dengue virus infection. Infect. Genet. Evol. 14, 390-395.

AlmARRI M. A., BERGSTRÖM A., PRADO-MARTINEZ J., Yang F., Fu B., DunhaM A. S., Chen Y., Hurles M. E., TYler-Smith C., XUE Y., 2020. Population structure, stratification, and introgression of human structural variation. Cell 182, 189-199. 
Anastassopoulou C., GKizarioti Z., Patrinos G. P., TSAKRIS A., 2020. Human genetic factors associated with susceptibility to SARS-CoV-2 infection and COVID-19 disease severity. Hum. Genomics 14, 1-8.

Benetti E., Tita R., Spiga O., Ciolfi A., Birolo G., Bruselles A., Doddato G., Giliberti A., Marconi C., Musacchia F., PIPPUCCI T., TORELLA A. i współaut., 2020. ACE2 gene variants may underlie interindividual variability and susceptibility to COVID-19 in the Italian population. Eur. J. Hum. Genet. 28, 16021614.

Castranova V., Rabovsky J., Tucker J. H., Miles P. R., 1988. The alveolar type II epithelial cell: A multifunctional pneumocyte. Toxicol. Appl. Pharmacol. 93, 472-483.

Chen L., Wolf A. B., Fu W., LI L., AKeY J. M. 2020. Identifying and interpreting apparent Neanderthal ancestry in African individuals. Cell 180, 677-687.

Chen Z., Desalle R., Schiffman M., HerRero R., Wood C. E., Ruiz J. C., Clifford G. M., CHAN P., BURK R. D., 2018. Niche adaptation and viral transmission of human papillomaviruses from archaic hominins to modern humans. PLoS Pathogens 14, doi.org/10.1371/ journal.ppat.1007352.

DANNEMANN M., KELSO J., 2017. The contribution of Neanderthals to phenotypic variation in modern humans. Am. J. Hum. Genet. 101, 578589.

DANNEMANN M., RACIMO F., 2018. Something old, something borrowed: admixture and adaptation in human evolution. Curr. Opin. Genet. Develop. 53, 1-8.

DANNEMANN M., ANDRÉS A. M., Kelso J., 2016. Introgression of Neandertal- and Denisovan-like haplotypes contributes to adaptive variation in human Toll-like receptors. Am. J. Hum. Genet. 98, 22-33.

DiNG Q., HU Y., XU S., WANG J., JIN L., 2014. Neanderthal introgression at chromosome $3 p 21.31$ was under positive natural selection in east asians. Mol. Biol. Evol. 31, 683-695.

Dolgova O., LAO O., 2018. Evolutionary and medical consequences of archaic introgression into modern human genomes. Genes 9, doi. org/10.3390/genes9070358.

ENARD D., PETROV D. A., 2018. Evidence that RNA viruses drove of adaptive introgression between Neanderthals and modern humans. Cell 175, 360-371.

Geoghegan J. L., Duchêne S., Holmes E. C., 2017. Comparative analysis estimates the relative frequencies of co-divergence and cross-species transmission within viral families. PLoS Pathogens 13, 1-17.

GHAFOURI-FARD S., NOROOZI R., VAFAEE R., BRANICKI W., POŚPIECH E., PYRĆ K., ŁABAJ P. P., OMRANI M. D., TAHERI M., SANAK M., 2020. Effects of host genetic variations on response to, susceptibility and severity of respiratory infections. Biomed. Pharmacother. 128, doi.org/https://doi.org/10.1016/j.biopha.2020.110296.

Green R. E., Krause J., Briggs A. W., Maricic T., Stenzel U., Kircher M., PATTERson N., L H., ZHAI W., FRITZ M. H. Y., HANSEN N. F., DURAND E. Y., MALASPINAS A. S. i współaut., 2010. A draft sequence of the neandertal genome. Science 328, 710-722.

Greenbaum G., Getz W. M., Rosenberg N. A., FELDMAN M. W., HOVERS E., KOLODNY O., 2019. Disease transmission and introgression can explain the long-lasting contact zone of modern humans and Neanderthals. Nat. Comm. 10, doi.org/10.1038/s41467-01912862-7.

Hackinger S., KraAiJenbrink T., Xue Y., MezZaVIlla M., ASAN VAN DRIEM G., Jobling M. A., DE KNIJfF P., TYler-Smith C., AYUB Q., 2016. Wide distribution and altitude correlation of an archaic high-altitude-adaptive EPAS1 haplotype in the Himalayas. Hum. Genet. 135, 393-402.

HARRIS K., NIELSEN R., 2016. The genetic cost of neanderthal introgression. Genetics 203, 881891.

HeIT J. A., 2012. Predicting the risk of venous thromboembolism recurrence. Am. J. Hematol. 87, 63-67.

Hoffmann M., Kleine-Weber H., Schroeder S., KRÜGER N., HERRLER T., ERICHSEN S., SCHIERGens T. S., Herrler G., Wu N. H., Nitsche A., MÜller M. A., Drosten C., PöhlmanN S., 2020. SARS-CoV-2 cell entry depends on ACE2 and TMPRSS2 and is blocked by a clinically proven protease inhibitor. Cell 181, 271-280.

Huerta-SÁnchez E., CASEy F. P., 2015. Archaic inheritance: Supporting high-altitude life in Tibet. J. Appl. Physiol. 119, 1129-1134.

Huerta-SÁnchez E., CASEY F. P., 2018. Simultaneous viral exposure and protection from $\mathrm{Ne}$ anderthal introgression. Cell 175, 306-307.

Huerta-SÁNCHEZ E., Jin X., ASAN BIANBA Z., PETER B. M., VINCKENBOSCH N., LIANG Y., YI X., He M., Somel M., Ni P., Wang B., OU X. i współaut., 2014. Altitude adaptation in Tibetans caused by introgression of Denisovan-like DNA. Nature 512, 194-197.

JABLONSKI N. G., 2021. The evolution of human skin pigmentation involved the interactions of genetic, environmental, and cultural variables. Pigment Cell Melanoma Res. 34, 707-729.

Jacobs L. C, Wollstein A., LaO O., Hofman A., KLAVER C. C., UitTERLinden A. G., NiJSTEN T., KAYSER M., LIU F., 2013. Comprehensive candidate gene study highlights UGT1A and BNC2 as new genes determining continuous skin color variation in Europeans. Hum. Genet.132, 147-158.

KHAYAT A. S., DE AsSUMPÇÃo P. P., KhaYAT B. C. M., ARaÚJo,T. M. T., Batista-Gomes J. A., IMBIRIBA L. C., ISHAK G., DE ASSUMPÇÃO P. B., MOREIRA F. C. i współaut., 2021. ACE2 polymorphisms as potential players in COVID-19 outcome. PLoS One, 15, 1-13.

Khor S. S., OMAe Y., Nishida N., SugiYama M., Kinoshita N., SuZUKI T., SuzUKI M., SUZUKI S., IzUMI S., HOJO M., OHMAGARI N., MizOKAMI M., TOKUNAGA K., 2021. HLA-A*11:01:01:01, HLA-C*12:02:02:01-HLA-B*52:01:02:02, age and sex are associated with severity of Japanese COVID-19 with respiratory failure. Front. Immunol. 12, doi.org/10.3389/fimmu. 2021.658570

Kist N. C., LAMBERT B., CAMPBell S., KatzouraKIS A., LunN D., LEMEY P., IVERSEN A. K. N., 2020. HIV-1 p24Gag adaptation to modern and archaic HLA-Allele frequency differences in ethnic groups contributes to viral subtype diversification. Virus Evol. 6, 1-18.

Krause J., Fu Q., GoOD J. M., ViOla B., SHunKOV M. V., DEREVIANKO A. P., PÄÄBO S., 2010. The complete mitochondrial DNA genome of an unknown hominin from southern Siberia. Nature 464, 894-897.

Kreuder Johnson C., Hitchens P. L., SMiley Evans T., Goldstein T., Thomas K., Clements A., JOLY D. O., WOlFE N. D., DASZAK P., KARESH W. B., MAZET J. K., 2015. Spillover and 
pandemic properties of zoonotic viruses with high host plasticity. Sci. Rep. 5, 1-8.

LeE J. W., LeE I. H., SATO T., Kong S. W., IIMURA T., 2021. Genetic variation analyses indicate conserved SARS-CoV-2-host interaction and varied genetic adaptation in immune response factors in modern human evolution. Develop. Growth Different. 63, 219-227.

Li Y., ZHANG Z., YANG L., Lian X., XIE Y., LI S., XIN S., CAO P., LU J., 2020. The MERS-CoV Receptor DPP4 as a Candidate Binding Target of the SARS-CoV-2 Spike. IScience 23, doi.org/10.1016/j.isci.2020.101160.

Lim J. K., Lisco A., MCDERMOTT D. H., Huynh L., WARD J. M., JOHNSON B., JOHNSON H., PAPE J., Foster G. A., Krysztof D., Follmann D., STRAMER S. L., MARGOlis L. B., MURPHY P. M., 2009. Genetic variation in OAS1 is a risk factor for initial infection with West Nile virus in man. PLoS Pathogens 5, doi.org/10.1371/ journal.ppat. 1000321 .

MendeZ F. L., WATKINS J. C., HAMMer M. F., 2013. Neandertal origin of genetic variation at the cluster of OAS immunity genes. Mol. Biol. Evol. 30, 798-801.

Migliorini F., TORsiello E., Spiezia F., Oliva F., TINGART M., MAFFUlLI N., 2021. Association between HLA genotypes and COVID-19 susceptibility, severity and progression: a comprehensive review of the literature. Eur. J. Med. Res. 26, 1-9.

Onofrio L., CARAglia M., FACChini G., MARGheRita V., Placido S. DE, BuOnerba C., 2020. Toll-like receptors and COVID-19: A two-faced story with an exciting ending. Future Sci. 6, 10-13.

Pairo-Castineira E., Clohisey S., Klaric L., BreTHERICK A. D., RAWLIK K., PASKO D., WALKER S., PARKINSON N., FOURMAN M. H., RUSSELL C. D., FURNISS J., RICHMOND A. i wspólaut. 2021. Genetic mechanisms of critical illness in COVID-19. Nature 591, 92-98.

PANCER K., MileWSKa A., OWCZAREK K., DABROWSKA A., KOWALSKI M., LABAJ P., BRANICKI W., SANAK M., PYRC K., 2020. The SARS-CoV-2 ORF10 is not essential in vitro or in vivo in humans. PLoS Pathogens 16, 1-8.

Pereira N. L., Ahmad F., Byku M., Cummins N. W., Morris A. A., Owens A., TUteJA S., CRESCI S., 2021. COVID-19: Understanding inter-individual variability and implications for precision medicine. Mayo Clinic Proc. 96, 446463.

Pickering C., Bergenheim V., Schiöth H. B., ERICSON M., 2008 Sensitization to nicotine significantly decreases expression of GABA transporter GAT-1 in the medial prefrontal cortex. Prog. Neuropsychopharmacol. Biol. Psychiatry 32, 1521-1526.

PIRET J., BOIVIN G., 2021. Pandemics throughout history. Front. Microbiol. 11, https://doi. org/10.3389/fmicb.2020.631736.

QUACH H., QUINTANA-MURCI L., 2017. Living in an adaptive world: Genomic dissection of the genus Homo and its immune response. J. Exp. Med. 214, 877-894.

Quach H., Rotival M., Pothlichet J., LOH Y. H. E., Dannemann M., Zidane N., LaVal G., PAtin E., HaRmant C., Lopez M., Deschamps M., NAFFAKH N. i współaut., 2016. Genetic adaptation and Neandertal admixture shaped the immune system of human populations. Cell 167, 643-656.

Racimo F., SANKararaman S., NiElsen R., HuERTA-SÁNCHEZ E., 2015. Evidence for archaic adaptive introgression in humans. Nat. Rev. Genet. 16, 359-371.

Rinker D. C., SimONTI C. N., MCARTHUR E., SHAW D., Hodges E., CAPRA J. A., 2020. Neanderthal introgression reintroduced functional ancestral alleles lost in Eurasian populations. Nat. Ecol. Evol. 4, 1332-1341.

Rogers A. R., HARRIS N. S., ACHENBACH A. A., 2020. Neanderthal-Denisovan ancestors interbred with a distantly related hominin. Sci. Advanc. 6, 1-8.

SAMS A. J., DUMAine A., NÉdÉlec Y., Yotova V., Alfieri C., TANner J. E., Messer P. W., BARREIRO L. B., 2016. Adaptively introgressed Neandertal haplotype at the OAS locus functionally impacts innate immune responses in humans. Genome Biol. 17, 1-15.

SANKARARAMAN S., MALlick S., DANNEMANN M., PRÜFER K., KElso J., PÄÄBO S., PATTERSON N., REICH D., 2014. The genomic landscape of Neanderthal ancestry in present-day humans. Nature 507, 354-357.

SimONTI C. N., VERnOT B., BASTARACHE L., BOTTINGER E., CARREll D. S., ChISHOlm R. L., CROSSLIN D. R., HEBBRING S. J., JARVIK G. P., Kullo I. J., LI R. i współaut., 2016. The phenotypic legacy of admixture between modern humans and Neandertals. Science 351, 737741.

Souilmi Y., Lauterbur M. E., TOBler R., Huber C. D., JOHAR A. S., MORADI S. V., JOHNSTON W. A., KROGAN N. J., AleXANDROV K., ENARD D., 2021. An ancient viral epidemic involving host coronavirus interacting genes more than 20,000 years ago in East Asia. Curr. Biol. 31, doi.org/10.1016/j.cub.2021.05.067.

STIKKER B., STIK G., HENDRIKS R. W., STADHOUdERS R., 2021. Severe COVID-19 associated variants linked to chemokine receptor gene control in monocytes and macrophages. BioRxiv, doi.org/doi.org/10.1101/2021.01.22.427813.

Sullivan A. P., DE MANUEl M., MARQUES-BONeT T., PERry G. H., 2017. An evolutionary medicine perspective on Neandertal extinction. J. Hum. Evol. 108, 62-71.

The Covid-19 Host Genetics Initiative, 2020. The COVID-19 Host Genetics Initiative, a global initiative to elucidate the role of host genetic factors in susceptibility and severity of the SARS-CoV-2 virus pandemic. Eur. J. Hum. Genet. 28, 715-718.

The Severe Covid-19 GWAS Group, 2020. Genomewide association study of severe COVID-19 with respiratory failure. New Engl. J. Med. 383, 1522-1534.

The Sigma (Slim Initiative in Genomic Medicine FOR THE AMERICAS) TYPE 2 DIABETES, CONSORTIUM, Williams A. L., JACOBS S. B., MORENo-Macías H., Huerta-Chagoya A., CHurchHOUSE C., MÁRQUEZ-LUNA C., GARCÍA-ORTíz H., Gómez-VÁzQuez M. J., BuRTt N. P., Aguilar-Salinas C. A., GonZÁleZ-VILlalPando C., Florez J. C., Orozco L., Haiman C. A., Tusié-Luna T., Altshuler D., 2014. Sequence variants in SLC16A11 are a common risk factor for type 2 diabetes in Mexico. Nature 506, 97-101.

Valverde P., Healy E., Sikkink S., Haldane F., THODY A. J., CAROTHERS A., JACKSON I. J., REES J. L., 1996. The Asp84Glu variant of the melanocortin 1 receptor $(M C 1 R)$ is associated with melanoma. Hum. Mol. Genet. 5, 1663-1666.

VAN DER MADE C. I., Simons A., SchuURS-HoEIJMAKers J., VAN Den Heuvel G., Mantere T., Kersten S., VAN DeURen R. C., STEehouW- 
ER M., VAN REIJMERSDAL S. V., JAEGER M. i współaut., 2020. Presence of genetic variants among young men with severe COVID-19. J. Am. Med. Assoc. 324, 663-673.

VERNOT B., AKeY J. M., 2014. Resurrecting surviving Neandertal lineages from modern human genomes. Science 343, 1017-1021.

Vernot B., Tucci S., Kelso J., Schraiber J. G., Wolf A. B., GitTelman R. M., Dannemann M., Grote S., McCoy R. C., NORTON H., ScheinFELDT L. B. i wspólaut., 2016. Excavating Neandertal and Denisovan DNA from the genomes of Melanesian individuals. Science 352, 235-239.

VishNUBHOTLA R., SASIKALA M., KeTAVARAPU V., REDDY D. N., 2021. High-resolution HLA genotyping identifies alleles associated with severe COVID-19: A preliminary study from India. Immun. Inflammat. Dis., doi.org/10.1002/ iid3.481.

Wang F., Huang S., GaO R., Zhou Y., Lai C., Li Z., XIAN W., QIAN X., LI Z., HuANG Y., TANG, Q., LIU P., CHEN R. i współaut., 2020. Initial whole-genome sequencing and analysis of the host genetic contribution to COVID-19 severity and susceptibility. Cell Discovery 6, doi. org/10.1038/s41421-020-00231-4

WANG H., LI X., Li T., ZHANG S., WANG L., Wu X., LIU J., 2020. The genetic sequence, origin, and diagnosis of SARS-CoV-2. Eur. J. Clin. Microbiol. Infect. Dis. 39, 1629-1635.

WARREN R. L., BIROL I., 2020. Retrospective in silico HLA predictions from COVID-19 patients reveal alleles associated with disease prognosis. MedRxiv : Preprint Server for Health Sci., doi.org/10.1101/2020.10.27.20220863.
WILls C. 2011. Genetic and phenotypic consequences of introgression between humans and Neanderthals. Adv. Genet. 76, 27-54.

ZAHID M. N., PERNA S., 2021. Continent-wide analysis of covid 19: Total cases, deaths, tests, socio-economic, and morbidity factors associated to the mortality rate, and forecasting analysis in 2020-2021. Int. J. Environ. Res. Publ. Health 18, https://doi.org/10.3390/ ijerph 18105350 .

ZEBERG H., PÄÄBO S., 2020. The major genetic risk factor for severe COVID-19 is inherited from Neanderthals. Nature 587, 610-612.

ZEBERG H., PÄÄBO S., 2021. A genomic region associated with protection against severe COVID-19 is inherited from Neandertals. Proc. Natl. Acad. Sci. USA 118, 3-7.

ZHANG T., Wu Q., ZHANG Z., 2020. Probable pangolin origin of SARS-CoV-2 associated with the COVID-19 outbreak. Curr. Biol. 30, doi. org/10.1016/j.cub.2020.03.063.

Zhou S., Butler-Laporte G., NaKanishi T., MoRRISON D. R., AFIlalo J., Afilalo M., LAURENT L., PIETZNer M., KERRISON N., ZHAO K. i współaut., 2021. A Neanderthal OAS1 isoform protects individuals of European ancestry against COVID-19 susceptibility and severity. Nat. Med. 27, 659-667.

Zietkiewicz E., Yotova V., Gehl D., WambaCh T., Arrieta I., Batzer M., Cole D. E. C., HeChtMAN P., KaPlan F., MOdiano D., Moisan J. P. MICHALSKI R., LABUDA D., 2003. Haplotypes in the dystrophin DNA segment point to a mosaic origin of modern human diversity. Am. J. Hum. Genet. 73, 994-1015. 
Kosmos Vol. 70, 3, 519-533, 2021

Kamila Marszatek, Kinga Herda, Pawet P. Łabaj, WoJciech Branicki

Malopolska Centre of Biotechnology Jagiellonian University, 7A Gronostajowa Str., 30-387 Kraków, E-mail: wojciech.branicki@uj.edu.pl

ARCHAIC HUMAN GENES IN THE GENOME OF MODERN HUMAN AND THE COVID-19 PANDEMIC

Summary

Palaeogenetic studies using high-throughput DNA sequencing revealed the genes of extinct human species in the genomes of modern humans. This is evidence of the crossing of our ancestors with the Neanderthal and Denisovian man in Asia and Europe. Moreover, this may indicate the adaptive benefits that modern man, occupying new geographic areas, gained as a result of acquiring new variants of genes from archaic species. One of the significant challenges our ancestors faced after leaving Africa were new pathogens, and viruses in particular. The analysis of modern genomes shows that genes inherited from our extinct relatives, coding for proteins of the immune system and proteins responsible for protection against viral infections, could help in the fight against them. It turns out that the genes present in the human genome, due to introgression, are also important in the confrontation with the SARS-CoV-2 virus, in particular, they affect the course of the COVID-19 disease. Interestingly, some of them, such as SLC6A20, LZTFL1, XCR1, and DPP4, may contribute to an increased risk of severe disease, while others, such as OAS1, OAS2, and OAS3, reduce this risk. Further research may shed light on the importance of these genetic variants in relation to past events that have led to an increase in their frequency in the genomes of modern humans. It is possible that viruses were an important selection factor that led to the presence of genes from extinct human species in the genomes of modern man, and these genes are evidence of past epidemics.

Key words: adaptation, Denisovian introgression, genes of extinct human species and COVID-19, human evolution,palaeogenetic research, Neanderthal introgression 